\author{
Celina SOŁEK-BOROWSKA ${ }^{1}$ \\ Katarzyna CHUDY-LASKOWSKA ${ }^{2}$
}

\title{
ASSESSING ENTREPRENEURIAL ATTITUDES AND SKILLS OF STUDENTS
}

\begin{abstract}
Entrepreneurship is often defined as the opportunistic pursuit of economic wealth by limited resources. Governments all over the world undertake many programmes to boost entrepreneurial spirits amongst students - potential entrepreneurs. The benefits gained are significant such as: job creation, innovation and ultimately contribution to national economic wealth. The role and effect of education, including training, on entrepreneurial activities has been a major topic of discussion in the last decade. The term "entrepreneurship education" refers to a holistic approach advocated in place of traditional schooling on the basics of how to run a business. The purpose of this study is to assess how grades obtained by students influence their entrepreneurial attitudes and secondly to assess students' entrepreneurial skills. Paper questionnaires were used to survey students studying at Warsaw School of Economics and Rzeszow University of Technology. The respondents were undergraduate students participating in the general module of Management at Warsaw School of Economics and Statistics Methods at Rzeszow University of Technology. The average grade students obtained during their studies strongly differentiates students plans considering what they are going to do after graduation. The more entrepreneurial students are those with average grade 3.5-3.99 as $19 \%$ of them would like to start their business. The best students (with higher grades) are the least entrepreneurial, just $6 \%$ of them would be willing to set up a business. This is a signal for educators that enterpreneurial attitudes can not be solely related to education but other factors must be taken into account such as individual predispositions e.g. wilingness to take a risk.
\end{abstract}

Keywords: entrepreneurship, entrepreneurship education, entrepreneurial skills.

\footnotetext{
${ }^{1}$ Celina Sołek-Borowska, PhD, Corporate Management Unit, Warsaw School of Economics, al. Niepodległości 162, 02-554 Warszawa, mail: csolek@sgh.waw.pl, (corresponding author), ORCID: 0000-0002-2411-9677.

Dr Celina Sołek-Borowska, Instytut Zarządzania, Kolegium Zarządzania i Finansów, Szkoła Główna Handlowa, al. Niepodległości 162,02-554 Warszawa, mail: csolek@sgh.waw.pl, autor korespondencyjny, ORCID: 0000-0002-2411-9677.

${ }^{2}$ Katarzyna Chudy-Laskowska, PhD, Qualitative Methods Department, Rzeszow University of Technology, Al. Powstańców Warszawy 8, 35-959 Rzeszów, mail: kacha877@prz.edu.pl, ORCID: 0000-0002-7797-2858.

Dr Katarzyna Chudy-Laskowska, Katedra Metod Ilościowych, Wydział Zarządzania, Politechnika Rzeszowska, Al. Powstańców Warszawy 8, 35-959 Rzeszów, mail: kacha877@ prz.edu.pl, ORCID: 0000-0002-7797-2858.
} 


\section{INTRODUCTION}

A growing academic interest in entrepreneurship has developed alongside different economic changes, such as globalisation ${ }^{3}$, acceleration of technological development ${ }^{4}$, innovation and business growth. This has led to rapid improvements in the competitive environment ${ }^{5}$ with organisations desperately needing to adapt to these changes and develop innovative products, services, processes, and business models. This situation requires being flexible and responsive toward changes. A dynamic economic development and several uncertainties had created numerous business opportunities for future entrepreneurs, including students at various levels of education, who noticed an opportunity to become committed entrepreneurs.

It is argued that individuals having a strong grip on specific entrepreneurial skills will probably feel more confident to start their own business, instead of working for any other organisation $^{6}$. Other than this, it can also be argued that a strong grip on entrepreneurial skills would also be associated with a higher attitude towards entrepreneurship ${ }^{7}$. Yet, it is unfortunate that the literature on entrepreneurship is generally underdeveloped and there is little research on of entrepreneurial skills and other initiatives of social support ${ }^{8}$.

The need to include enterprise and entrepreneurship studies in the education system, at all levels, has gained much attention from academia and governments all over the world. This prolonged and heightened interest in entrepreneurship is prompted by several factors. First, for developed economies, entrepreneurial activity (new venture formation) is a way of revitalizing stagnated economies and of coping with unemployment problems by providing new job opportunities. Moreover, entrepreneurship is a great force for economic growth, recovery and society progress speaking of employment, social empowerment and innovation ${ }^{9}$. However, we claim it has a more critical role for economies of developing countries as entrepreneurship is perceived as an engine of economic progress, job creation and social adjustment. Thus, small business growth/new business formation is widely encouraged by national economic policies to stimulate economic growth and wealth creation.

Although many universities in the world offer courses on entrepreneurship, little evidence is available about students taking these courses and their intentions to become entre-

${ }^{3}$ E. Gummesson, Relationship marketing in the new economy, ,Journal of Relationship Marketing”, Vol. 1 No. 1, 2002, pp. 37-58.

${ }^{4}$ M. Santoro, A.K. Chakrabarti, Firm size and technology centrality in industry-university interactions, ,Research Policy”, Vol. 31, 2003, p. 1163-80.

5 J.A. Siguaw, T.L. Bakes, P.M. Simpson, Preliminary evidence on the composition of relational exchange and its outcomes: the distributor perspective, „Journal of Business Research”, Vol. 56, 2003, p. 311-22.

${ }^{6}$ M.S. Farooq, M. Salam, S. UrRehman, A. Fayolle, N. Jaafar, K. Ayupp, Impact of support from social network on entrepreneurial intention of fresh business graduates: a structural equation modeling approach, "Education + Training", Vol. 60 No. 4, 2018, p. 1-19.

7 M. Salam, D.N.F.A Iskandar, D.H.A. Ibrahim, Service learning support for academic learning and skills development, Journal of Telecommunication, Electronic and Computer Engineering, Vol. 9, No. 2-10, 2017, p. 111-117.

${ }^{8}$ S. Adomako, A. Danso, A., M. Uddin and J. O. Damoah (2016), Entrepreneurs' optimism, cognitive style and persistence, "International Journal of Entrepreneurial Behavior \& Research", Vol. 22, No.1, 2016, pp. 84-108.

9 B.A. Soomro, N. Shah, Developing attitudes and intentions among potential entrepreneurs, "Journal of Enterprise Information Management” 2015, Vol. 28 Issue: 2, p. 304-322. 
preneurs ${ }^{10}$. Roxas et al. (2008) $)^{11}$ claim that knowledge gained from formal entrepreneurship education programmes will boost individual entrepreneurial intentions. The idea of the entrepreneurial university has recently entered into the debate ${ }^{12}$. It is argued that a country's development and economic growth can be achieved by promotion of enterprise education among students a trait that requires knowledge of entrepreneurshi, financial resources and the business environment ${ }^{13}$. The review by Gorman et al. ${ }^{14}$ indicates that by aligning education with entrepreneurship, countries lacking resources and employment opportunities can foster entrepreneurial attributes, and the potential of students, which in turn could bring several economic benefits.

The aims of this research are twofold. Firstly to determine enterpreneurial attitudes of students considering the grades they obtain during their studies and secondly to assess students entrepreneurial skills.

To this end two institutions were studied: the Warsaw School of Economics (SGH) and Rzeszow University of Technology (PRZ). The remainder of this study is structured as follows. Section 2 reviews the literature on concept of entrepreneurship, entrepreneurial skills and entrepreneurship education followed by the development of research questions, research design and methodology in section 3 . The empirical results and discussion of the findings are presented in section 4.

\section{THEORETICAL BACKGROUND}

\subsection{Defining entrepreneurship}

As research on entrepreneurship shows, there is no universal definition or concept of entrepreneurship in existing organizations ${ }^{15}$. Instead, the concept is rich with different approaches and assumptions. Therefore there is no single construct of entrepreneurship, which results in different operationalizations of this concept ${ }^{16}$.

${ }^{10}$ A. Basu, M. Virick, Assessing entrepreneurial intentions amongst students: a comparative study, 2008, www.researchgate.net/publication/255583956_Assessing_Entrepreneurial_Intentions_ Amongst_Students_A_Comparative_Study (access: 21 January 2016).

11 B.G. Roxas, R. Cayoca-Panizales, Entrepreneurial knowledge and its effects on entrepreneurial intentions: development of a conceptual framework. "Asia-Pacific Social Science Review", Vol. 8, No. 20, 2008, p. 61-77.

${ }^{12}$ P. McGowan, P. Sijde, D. Kirby, The role of universities in the entrepreneurship industry: promoting the entrepreneurship agenda in HEIs, "Industry and Higher Education", Vol. 22 No. 1, 2008, p. 49-59.

${ }^{13}$ P. Milius, J. Sarkiene, Entrepreneurship training for innovative start-ups: the KTC case, in van der P. Sijde, Annemarie Ridder, A., Blaauw, G. and Diensberg, C. (Eds), Teaching Entrepreneurship, 2008, ISBN 978-3-7908-2038-6, Physica-Verlag HD, Heidelberg, pp. 23-33.

${ }^{14}$ G. Gorman, D. Hanlon, W. King, Some research perspectives on entrepreneurship education, enterprise education and education for small business management: a ten-year literature review. "International Small Business Journal" 1997, Vol. 15 No. 3, p. 56-77.

${ }^{15}$ P. Davidsson, Research Entrepreneurship. Springer, New York; Idem: The Domain of Entrepreneurship Research: Some Suggestions. In: „Advances in Entrepreneurship, Firm Emergence and Growth" 2005, Ed. J.A. Katz.

16 W. Dyduch, Corporate entrepreneurship measurement for improving organizational performance, „Journal of Economics and Management” 2008, Vol. 4, p. 15-40. 
Research literature reveals entrepreneurship as a socioeconomic force, a state of mind in the business economy which can generate employment opportunities, particularly new businesses, via intuitive ability, instincts, unique values, attitudes and skills ${ }^{17}$. The impact of entrepreneurship is always seen as positive in the economy. Entrepreneurial activities are on the rise globally, with many governments taking deliberate action to encourage and increase the formation of start-ups and new ventures (GEM, 2009, 2014). For the purpose of this paper, we assume that entrepreneurship is related with setting up your own company and in such context we consider it.

\subsection{Concept of entrepreneurial skills}

The perception about entrepreneurial skills indicates the self-confidence of respondents about certain skills which are critical for being an entrepreneur ${ }^{18}$. It is expected that, a high level of entrepreneurial skills will positively influence the personal attitude towards entrepreneurship, subjective norms and perceived behavioural control ${ }^{19}$. According to Liñán $(2008)^{20}$, the perception towards entrepreneurial skills indicates how much individuals are confident about their possession of entrepreneurial skills which are required for founding a new business (p. 261). Further on, in this regard, he argues that certain skills are required for any individual to become an entrepreneur, and these skills can be categorised as entrepreneurial skills. According to Denoble et al. ${ }^{21}$, the possession of entrepreneurial skills could increase individuals' confidence level and it makes them feel more able to start their own business. They argue that these entrepreneurial skills could be exercised in a better way as an entrepreneur, because the possession of entrepreneurial skills increases personal self-efficacy of potential entrepreneurs. Moreover, Salam et al. ${ }^{22}$ and Scherer et al. ${ }^{23}$ assert that having possession of entrepreneurial skills gives internal motivation and desire to excel;

17 Z.J. Acs, M.I. Megyesi, Creativity and industrial cities: a case study of Baltimore, "Entrepreneurship and Regional Development: An International Journal" 2009, Vol. 21 No. 4, p. 421-439; A. Azhar, A. Javaid, M. Rehman, A. Hyder, Entrepreneurial intentions among business students in Pakistan. "Journal of Business Systems, Governance and Ethics" 2010, Vol. 5 No. 2, p. 13-21; V. Johansen, T. Schanke, T. H. Clausen, "Entrepreneurship education and pupils: attitudes towards entrepreneurs" 2010, available at: www.intechopen.com (access: 11 August 2013).

${ }_{18}$ M.S. Farooq, Social support and entrepreneurial skills as antecedents of entrepreneurial behaviour, $\mathrm{PhD}$ thesis, Universiti Malaysia Sarawak (UNIMAS), Sarawak, 2016 available at: https:// ir.unimas.my/19807/ (accessed 17 March 2018).

${ }^{19}$ M.S. Farooq, M. Salam, S. UrRehman, A. Fayolle, N. Jaafar, N. and K. Ayupp, Impact of support from social network on entrepreneurial intention of fresh business graduates: a structural equation modeling approach, "Education + Training" 2018, Vol. 60, No. 4, p. 1-19.

${ }^{20}$ F. Liñán, Skill and value perceptions: how do they affect entrepreneurial intentions?, "International Entrepreneurship and Management Journal" 2008, Vol. 4, No. 3, p. 257-272.

21 A.F. Denoble, K. Jung, S.B. Ehrlich, Entrepreneurial self-efficacy: the development of a measure and its relationship to entrepreneurial action, in Reynolds, P.,Bygrave,W.,Manigart,S., Mason, C., Meyer, G.D., Sapienza, H.J. and Shaver, K.G. (Eds), "Frontiers of Entrepreneurship Research", Babson College, Wellesley, MA, 1999, p. 2881-2888.

${ }^{22}$ M. Salam, D.N.F.A. Iskandar, D.H.A Ibrahim, Service learning support for academic learning and skills development, "Journal of Telecommunication, Electronic and Computer Engineering" 2017, Vol. 9, No. 2-10, 2017, p. 111-117.

${ }^{23}$ R.F., Scherer, J.D., Brodzinski, F. Wiebe, Examining the relationship between personality and entrepreneurial career preference, Entrepreneurship \& Regional Development, 1991, Vol. 3, No. 2, p. 195-206. 
as a result, perceived chances of success as an entrepreneur become higher for those who possess entrepreneurial skills. Moreover, Liñán (2008) argues that entrepreneurial skills have a positive relation with personal attraction towards entrepreneurship. Farooq et al. ${ }^{24}$ claim that the possession of entrepreneurial skills has a psychological effect on individuals' attitude, which empowers and leads a person towards entrepreneurial behaviour in the future. On the basis of above discussion, this study assumes that there is a probability of high correlation between entrepreneurial skills and entrepreneurial attitude.

Research has shown that entrepreneurial skills can be learned ${ }^{25}$, which has lead to an increase in the number of entrepreneurship programs at colleges and universities ${ }^{26}$.

\subsection{Entrepreneurship education}

Entrepreneurship education has received significant attention from scholars, educators, practitioners and policy-makers ${ }^{27}$. Entrepreneurial education is perceived as one of the most important challenges of modern educational systems and socio-economic development. Although entrepreneurial education is currently a hot topic in the literature on entrepreneurship worldwide, it is only an emerging subject in Poland, although it is increasingly undertaken by researchers in various fields ${ }^{28}$.

Entrepreneurship education while transferring content knowledge and developing skills and competencies, should also stimulate intentions and mindsets that promote entrepreneurial behaviours and activities ${ }^{29}$.

According to Reynolds et al..$^{30}$ appropriate education and training programs in entrepreneurship are expected to increase the number of people becoming entrepreneurs because the better educated the population the higher the level of entrepreneurial activity. There has been a notable expansion in the number of entrepreneurship programmes globally in recent

${ }^{24}$ M.S Farooq, M. Salam, N. Jaafar, A. Fayolle, K. Ayupp, M. Radovic-Markovic and A. Sajid, Acceptance and use of lecture capture system (LCS) in executive business studies: extending UTAUT2, "Interactive Technology and Smart Education" 2017, Vol. 14, No. 4, p. 329-348.

${ }_{25}$ D. Kuratko, The emergence of entrepreneurship education: developments, trends, and challenges, "Entrepreneurship Theory \& Practice" 2005, Vol. 29, No. 5, p. 577-97.

${ }^{26}$ H. Matlay, Researching entrepreneurship and education: what is entrepreneurship and does it matter?, Education p Training, Vol. 47, No. 8/9, 2005, p. 665-77.

${ }^{27}$ S.M., Lee, D. Chang, and S.B. Lim, Impact of entrepreneurship education: a comparative study of the US and Korea, "The International Entrepreneurship and Management Journal" 2005, Vol. 1, No. 1, p. 27-43; C. Winkler, Toward a dynamic understanding of entrepreneurship education research across the campus-social cognition and action research, "Entrepreneurship Research Journal" 2014, Vol. 4, No. 1, p. 69-93.

${ }^{28} \mathrm{~K}$. Wach, Edukacja przedsiębiorcza: analiza bibliometryczna polskiego piśmiennictwa (Entrepreneurship: bibliometric analysis of Polish literature), „Horyzonty Wychowania” 2016, Vol. 15, No. 34, p. 11-26.

${ }^{29}$ Y. Zhang, G. Duysters, M. Cloodt, The role of entrepreneurship education as a predictor of university students' entrepreneurial intention, "International Entrepreneurship and Management Journal" 2014, Vol. 10, No. 3, p. 623-641.

30 P.D. Reynolds, M. Hay, S.M. Camp, Global Entrepreneurship Monitor: 1999 Executive Report, Kauffman Centre for Entrepreneurial Leadership at the Ewing Marion Kauffman Foundation, Kansas City, 1999, MO. 
times $^{31}$, although participation does not always lead to nascent entrepreneurship ${ }^{32}$. This has often been driven by the belief that education is best placed to equip students with the necessary knowledge and skills required to prosper in working environments ${ }^{33}$. In terms of the entrepreneurial experience however, there is ongoing debate regarding the essential attitudes towards education components of an effective entrepreneurship education programme $^{34}$. Indeed, Anderson and $\mathrm{Jack}^{35}$ argue that entrepreneurship education is a difficult area to lecture on due to its variability, complexity and contingency.

Despite this increased attention, the legitimacy of entrepreneurial education is far from well established ${ }^{36}$.

We consider entrepreneurship education as an important part of managerial education which we perceived in a wider perspective. We believe that entrepreneurial competencies are not limited to those that aim to set up a new business venture. We think, that entrepreneurial competencies are important to managers, specialists or almost any employee working in a contemporary, fast changing organizations. For us being entrepreneurial means to be innovative, looking for new opportunities, undertaking new initiatives. Those people with such skills can work for any type of business.

Business and management school graduates are expected to possess appropriate knowledge, skills and social competencies. Some of them will become managers, company owners and should help to guide us through the turbulent world of modern organizations ${ }^{37}$.

\section{RESEARCH METHODOLOGY}

The research was undertaken at Warsaw School of Economics and Rzeszow University of Technology in the summer semester of May 2016. The students at both Universities were asked to complete a paper questionnaire which would assess their entrepreneurial attitudes. Students were assured of anonymity in the reported results and could withdraw their participation at any time. As a pilot study, we developed an online version of the questionnaire which was sent first to five students and five other academics to check if the questions are properly understood and to check validity.

${ }^{31}$ J. Katz, Chronology and intellectual trajectory of American entrepreneurship education 1876-1999, "Journal of Business Venturing” 2003, Vol. 18 No. 2, 2003, p. 283-300.

${ }^{32}$ D.F. Kuratko, The emergence of entrepreneurship education: development, trends and challenges. "Entrepreneurship Theory and Practice", Vol. 29 No. 5, 2005, pp. 577-97; H. Matlay, C. Carey, Entrepreneurship education in the UK: a longitudinal perspective. "Journal of Small Business Enterprise and Development" 2007, Vol. 14 No. 2, 2007, p. 252-63.

33 A. Adcroft, S. Dhaliwa, R. Willis, Insatiable demand or academic supply: the intellectual context of entrepreneurship education. "European Business Review" 2005, Vol. 17 No. 6, 2005, p. 518-31.

${ }^{34}$ L. Pittaway, J. Cope, Entrepreneurship education: a systematic review of the evidence. Working Paper Series No. 2, National Council for Graduate Entrepreneurship, Birmingham, 2006, p. 1-33.

35 A. Anderson and S. Jack, Role typologies for enterprising education: the professional artisan?. "Journal of Small Business and Enterprise Development" 2008, Vol. 15 No. 2, p. 259-73.

${ }^{36}$ E. Abaho, D.R. Olomi, G.C. Urassa, Students' entrepreneurial self-efficacy: does the teaching method matter?, "Education + Training" 2015, Vol. 57, No. 8/9, p. 908-923.

${ }^{37}$ M. Kostera, Differing..., p. 673-97. 
The presented results cover the responses from two Universities. We aimed to present a short characteristics of two Universities to acquaint readers with a profile of two Universities.

\subsection{Warsaw School of Economics}

Warsaw School of Economics (SGH) is considered to be one of the best business-oriented universities in Poland. It is famous for its links with businesses, and accreditations. There is a very strong link with businesses that is visible through courses run by academic teachers and managers from companies. Moreover, student organisations are very active in organising events like the Marathon of consulting firms or exhibition days. Students drive to create a platform of communication between the best students and market leaders, and they highlight that international corporations are the best places to start their business career $^{38}$.

The presence at SGH of global companies like McKinsey, Procter and Gamble, L'Oréal Polska, Deloitte or Ernst and Young is a confirmation of the high level of teaching who are looking for high calibre of students. Companies have the opportunity to engage with potential employees and students can acquaint themselves with the business world. The relationship is beneficial to both parties.

\subsection{Rzeszow University of Technology}

Rzeszow University of Technology (PRz) is located in the south-eastern part of Poland. $\mathrm{PRz}$ is recognised amongst the best technical universities in Poland. The Management Faculty was set up in 1993 in response to increased demand for management education. The business links are well established with Aviation Valley, which supports automotive and aviation provision companies.

The Business Council was created in 2012 on the initiative of the Dean's office, with associate business leaders operating mainly in Podkarpackie Province. The main goal of the Council is the formation of a platform to advise on creating high quality scholarly achievements, modernization of teaching processes, initiation of business contacts and initiating promotional and marketing activity. It is the task of the Business Council to improve the exchange of experience between academic teachers and practitioners of management. The latest initiative was the world entrepreneurship week organized in November in 2017.

\subsection{Sample}

The study involved 566 students. The research was conducted at two universities: in Rzeszow (Ignacy Łukasiewicz University of Technology) where students constituted 46\% of the respondents and in Warsaw (Warsaw School of Economics) where students constituted $54 \%$. The research results include tThe proportion of female students and male students was around $50 \%$. The majority of respondents had an average of grade 4 and above (slightly over 66\%). Most of them were first year students (75\% of the study group). The "other" option includes third-year students and masters students]. The most-represented discipline is Finance (27\%), International Relations (27\%) and Logistics (17\%). Other disciplines include economics, e-business, econometrics, computer science and data analysis.

\footnotetext{
${ }^{38}$ Exhibition leaflet, Exhibition of FMCG, prepared by the Students' Association at SGH.
} 
Table 1. Characteristic of the sample

\begin{tabular}{|c|c|c|c|}
\hline & & Sample size & Percentage \\
\hline $\begin{array}{l}\text { Gender } \\
\text { [3 persons did not answer } \\
\text { this question] }\end{array}$ & $\begin{array}{l}\text { Women } \\
\text { Men }\end{array}$ & $\begin{array}{l}227 \\
286\end{array}$ & $\begin{array}{l}49.2 \% \\
50.8 \%\end{array}$ \\
\hline $\begin{array}{l}\text { Average grade } \\
\text { [24 persons did not } \\
\text { answer this question] }\end{array}$ & $\begin{array}{l}\text { from } 3.0 \text { up to } 3.49 \\
\text { from } 3.5 \text { up to } 3.99 \\
\text { from } 4.0 \text { up to } 4.4 \\
\text { from } 4.5 \text { up to } 5.0\end{array}$ & $\begin{array}{c}12 \\
170 \\
271 \\
89 \\
\end{array}$ & $\begin{array}{c}2.2 \% \\
31.4 \% \\
50 \% \\
16.4 \% \\
\end{array}$ \\
\hline $\begin{array}{l}\text { Discipline/ Specialization } \\
\text { [15 persons did not ans- } \\
\text { wer this question] }\end{array}$ & $\begin{array}{l}\text { Finance } \\
\text { Management } \\
\text { International relations } \\
\text { Logistics } \\
\text { Quantitative methods and information systems } \\
\text { Other }\end{array}$ & $\begin{array}{c}148 \\
51 \\
148 \\
93 \\
58 \\
53\end{array}$ & $\begin{array}{c}26.9 \% \\
9.3 \% \\
26.9 \% \\
16.9 \% \\
10.5 \% \\
9.6 \% \\
\end{array}$ \\
\hline $\begin{array}{l}\text { Year of study } \\
\text { [4 persons did not answer } \\
\text { this question] }\end{array}$ & $\begin{array}{l}\text { 1st year } \\
\text { 2nd year } \\
\text { 3rd year }\end{array}$ & $\begin{array}{c}424 \\
99 \\
39\end{array}$ & $\begin{array}{c}75.4 \% \\
17.6 \% \\
7 \% \\
\end{array}$ \\
\hline Place & $\begin{array}{l}\text { Rzeszow } \\
\text { Warsaw }\end{array}$ & $\begin{array}{l}260 \\
306\end{array}$ & $\begin{array}{l}54 \% \\
46 \%\end{array}$ \\
\hline
\end{tabular}

Source: Own development, based on: C. Sołek-Borowska, K. Chudy-Laskowska, Exploring entrepreneurial attitudes of students in Poland: An interregional comparison, Katowice 2017, p. 141-162.

The research questions are as follows:

- RQ (1) What are the entrepreneurial attitudes of students considering average grades? (Do students with best grades are more entrepreneurial?

- RQ (2) What is the role of education sector in promoting entrepreneurial attitudes?

- RQ (3) How do students assess their entrepreneurial skills?

To answer the first and second research questions we used Chi square Independence test. To answer the third research question we used U Manna - Whitney'a test to assess the level of entrepreneurial skills in two groups (one group of students who are willing to start their own business and the second one, students who want to work for someone)

The hypothesis sound as follows:

- $\mathrm{H}_{1}$ : Students average grade did not influence their entrepreneurial attitude

- $\mathrm{H}_{2}$ : There are not statistically significant differences as to the role of education between students who would be willing to set up their own business and those who would like to work for someone else

- $\mathrm{H}_{3}$ : There are not statistically significant differences betwen students as to their assessment of their entrepreneurial skills

It is recognized that, whilst there is a body of literature on entrepreneurial intentions and attitudes, there is a lack of research devoted to entrepreneurial attitudes and skills considering students grades. Many times assumption is made that students with best grades will be most entrepreneurial and we either want to confirm or reject our hypothesis. Therefore, this reaserch offers a new perspective to analyze the grades students obtain during their studies and their entrepreneurial propensity. The current paper adds to this body of literature and makes a significant contribution to the research on factors influencing entrepreneurial attitudes considering students' grades. 


\section{RESEARCH FINDINGS}

According to Safin $^{39}$ there is a conviction in Polish society that a successful career of a young person is related to finding interesting work in a large company, rather than the establishment of his own company. Such a view is influenced not only by the recent past, in which the company was a rather marginal and often forced undertaking, but also a contemporary assessment of the professional prestige of the entrepreneur. According to the „Rzeczpospolita“ daily rankings, the entrepreneur is in a distant position. Although a relatively high-value entrepreneur enjoys a high reputation (but it is relatively rare to find a wealthy entrepreneur), small entrepreneurs, who account for $90 \%$ of all companies in Poland, enjoy the same status as a person without a profession.

\subsection{Willingness to set up a business when considering student's grades}

In order to answer the first research question RQ1 and confirm or reject $\mathrm{H}_{1}$ hypothesis we asked students the following question: „What are you planning to do after graduation“. $12 \%$ students consider of setting up their business straight away after graduation ${ }^{40}$. As we are interested if very good students or average students are entrepreneurially inclined, the Fig. 1 presents the answers with consideration of grades presented.

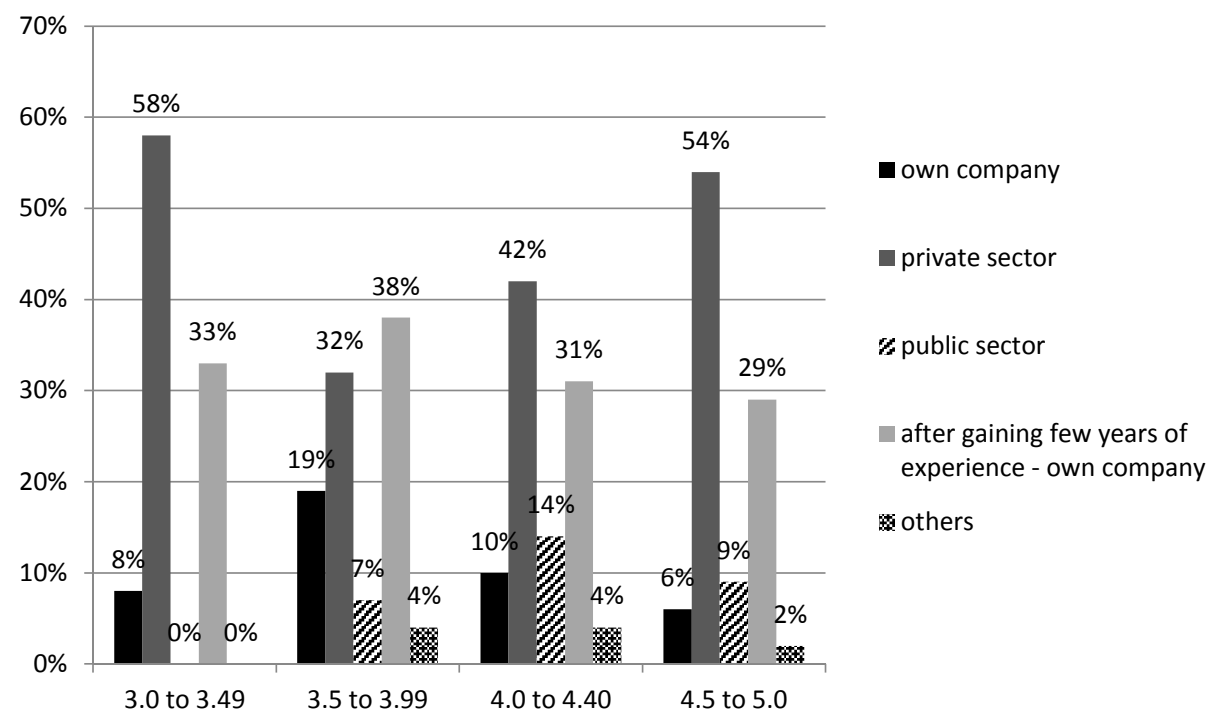

Figure 1. Employment plans after graduation with the consideration of grades obtained during the study

Source: Own development, $\mathrm{n}=566$.

${ }^{39}$ K. Safin, Przedsiębiorcze zachowania studentów - stan i konsekwencje dla dydaktyki (Entrepreneurship of students - the current state and the consequences for didactics), "Horyzonty Wychowania" 2014, Vol. 13, No. 26, p. 327-340.

40 The detailed results considering the entrepreneurial attitudes can be found in the paper: C. Sołek-Borowska, K. Chudy-Laskowska, Exploring..., p. 141-162. 
In order to confirm or reject $\mathrm{H}_{1}$ hypothesis the Chi square Independence test $\left(\chi^{2}\right)$ has been utilised. The average grade which students obtained during their studies strongly differentiates students plans considering what they are going to do after graduation $\mathrm{p}<\alpha$ $(\mathrm{p}=0,00375)$. The more entrepreneurial students are those with average grade starting from 3.5 up to 3.99 as $19 \%$ of them would like to start their business just after graduation. The trend is not changing considering setting up a business after gaining a few years of experience, where $38 \%$ of students with average grade 3.5 up to 3.99 are willing to set it up. The best students are the least enterpreneurial, only $6 \%$ of them are willing to set up their own business. This is a strong evidence that enterpreneurial students are not those with higher grades but average students. The good students (with average grade 4.0-4.4) would like to work in public sector which is not prevailing amongst the students with lowest average grade (3.00-3.49). The obtained results can refer to other aspects of seeting up a business which is willingness to take a risk for yourself, your company and your employees. We can definetely confirm that the best students are not the most enterpreneurial. On the contrary, the average students seem to be more entrepreneurial which is proved when we compare the aspect of setting up a business straight away and after few years of gaining experience with other options (working in private sector and public secor) what is presented in Fig. 2.

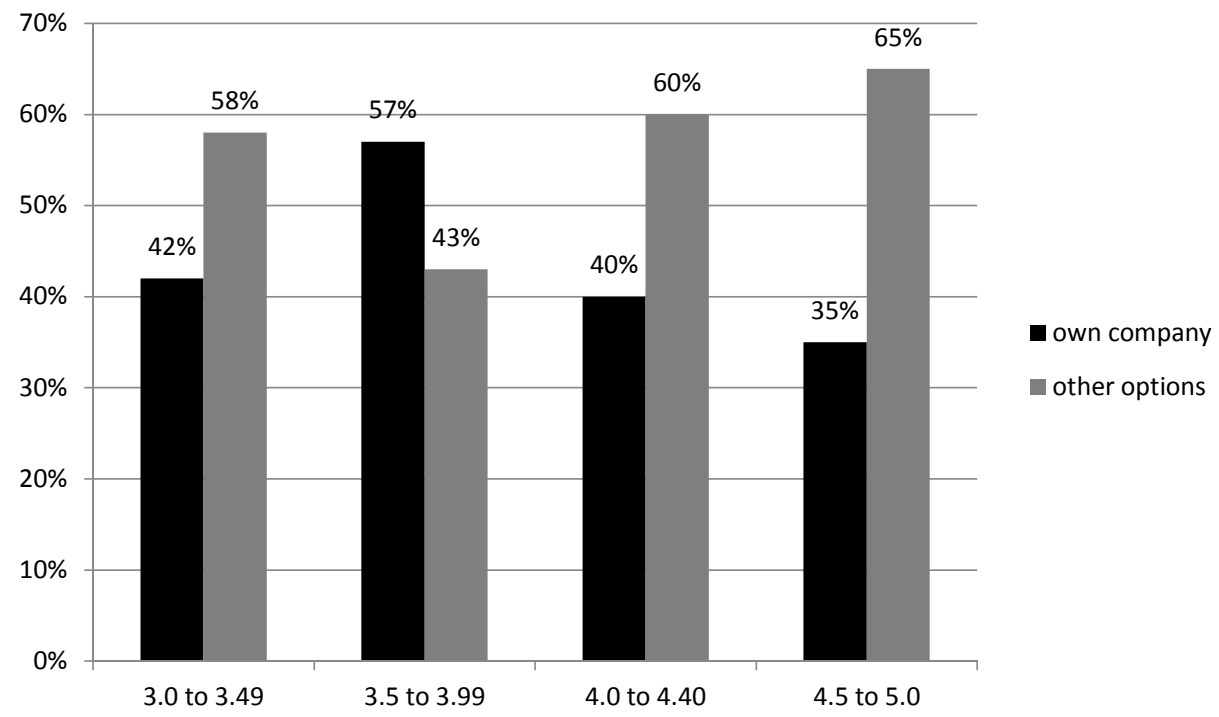

Figure 2. Own company versus other possibilities of employment

Source: Own development, $\mathrm{n}=566$.

We meant to analyse two group of students: one -who are willing to set up a business and the second one who are willing to work for someone else. We used also Chi squate stiatistics $\left(\chi^{2}\right)$ to test if the willingness to set up the business is the same in two groups. The test proved significant dependence between the obtained grade and the willingness to set up a business $\mathrm{p}<\alpha(\mathrm{p}=0,001)$. Therefore we can state that best grades are not a prerequisite for entrepreneurial attitudes. The more entrepreneurial are students with average grades 3.5 up 
to 3.99. On the contrary, the best students are the least enterpreneurial. We reject $\mathrm{H}_{1}$ hypothesis, the grades students obtained influenced their enterpreneurial attitudes. This is an important signal for educators which drives the research further to analyze the risk attitudes.

\subsection{Education and students' entrepreneurial skills}

Education is one of the factors that stimulate entrepreneurship, especially in terms of fostering entrepreneurial awareness ${ }^{41}$. The idea is that how entrepreneurship attitudes can be developed which is actually related with the mindset of individuals.

Programs that support entrepreneurship through financial grants, training and internships do not appear to deliver the expected results and end their lives at the end of the required period. One of the main reasons is the ineffective education process in this context as noted by Safin $(2014)^{42}$.

We wanted to assess the role of education in promoting entrepreneurial attitudes by finding the answer for a second research question.

Students were asked whether one can learn to be an entrepreneur. More than half [56\%] of students claim that entrepreneurship is partly learned. Therefore the next question followed: do you think that the education you are gaining at university by participating in different modules enhances your entrepreneurship skills? Students could select from 1 - I strongly disagree to 5 - I strongly agree using the Likert scale. The results are presented in Fig. 3.

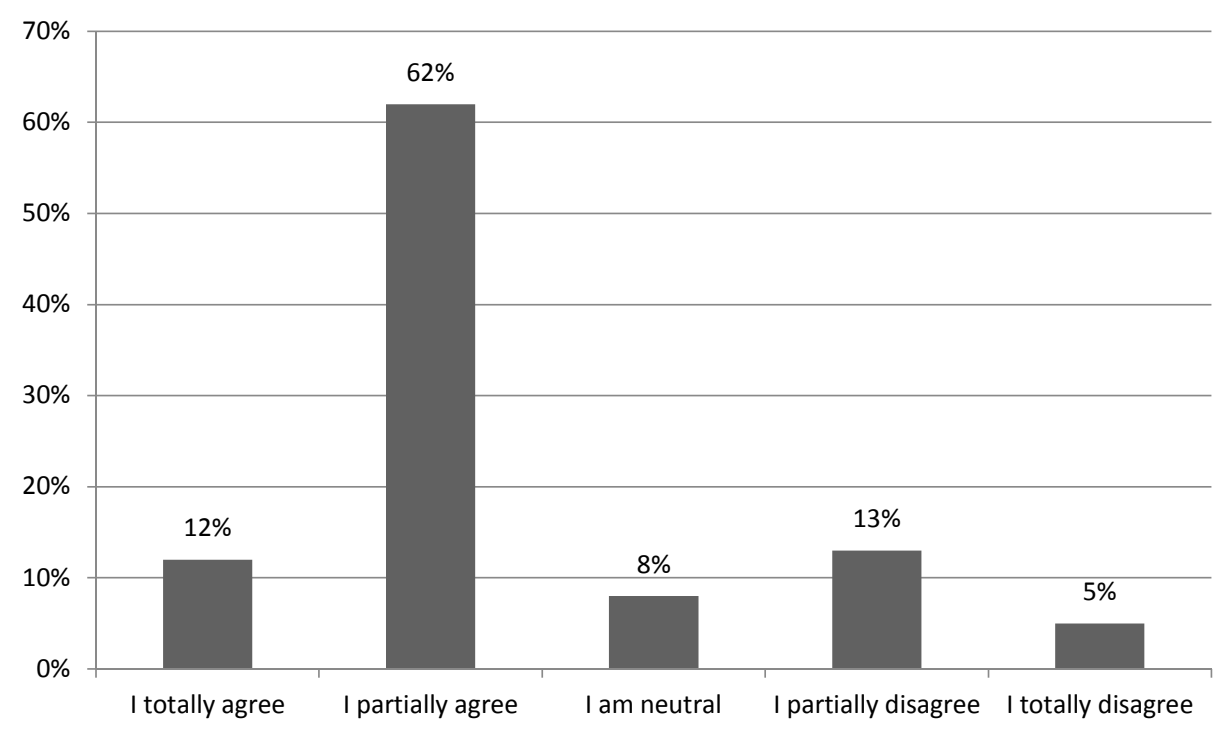

Figure 3. Education in entrepreneurship

Source: Own development, $\mathrm{n}=566$.

${ }^{41}$ K. Wach, Edukacja..., p. 11-26.

${ }^{42}$ K. Safin, Przedsiębiorcze..., p. 327-340. 
To confirm or reject $\mathrm{H}_{2}$ hypothesis we used Chi squate Independence test. We aimed to investigate whether there are differences in the answers of students who would be willing to set up a business and those who would like to work for someone else. Using Chi Square Independence test, $\mathrm{p}>\alpha(\mathrm{p}=0,47365)$ indicates there are not differences in answers. We can confirm $\mathrm{H}_{2}$ hypothsis there are not statisticcaly diffeerences between between two group of students as to the role of education.

\subsection{Student's assessment of entrepreneurial skills}

According to Liñán $(2008)^{43}$, the perception towards entrepreneurial skills indicates how much individuals are confident about their possession of entrepreneurial skills which are required for founding a new business. In this regard, he further argues that certain skills are required for any individual to become an entrepreneur, and these skills can be categorised as entrepreneurial skills ${ }^{44}$. For the purpose of this study, entrepreneurial skills are adapted from numerous previous studies.

Moreover, Denoble et al. (1999) argue that the possession of these entrepreneurial skills could increase individuals' confidence level and can make them feel more able to start their own business. Further, they argue that these entrepreneurial skills could be exercised in a better way as an entrepreneur because the possession of these skills increases personal self-efficacy of potential entrepreneurs. To answer the third research questions we asked students to assess their entrepreneurial skills.

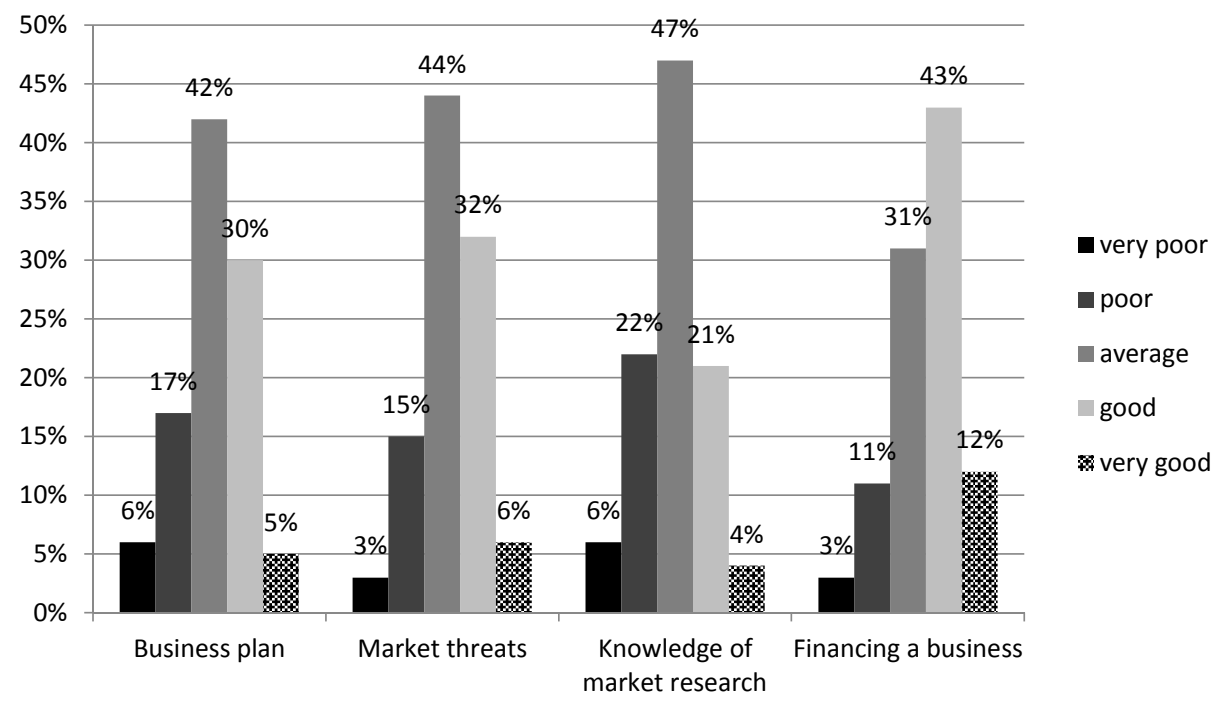

Figure 4. Students assessment of entrepreneurial skills

Source: Own development, $\mathrm{n}=566$.

${ }^{43}$ F. Liñán, Skill and value perceptions: how do they affect entrepreneurial intentions?, "International Entrepreneurship and Management Journal" 2008, Vol. 4, No. 3, p. 257-272.

${ }^{44}$ M.S. Farooq, M. Salam, S. UrRehman, A. Fayolle, N. Jaafar, K. Ayupp, Impact of support from social network on entrepreneurial intention of fresh business graduates: a structural equation modeling approach, "Education + Training" 2018, Vol. 60, No. 4, p. 1-19. 
We took into account the following entrepreneurial skills: ability to prepare a business plan, knowledge of market threats, knowledge of market research techniques and knowledge how to finance a business. Students were asked how they assess their skills on the scale from 1 not at all to 5 outstanding. The results are presented in Fig. 4.

The highest grade students apppointed to knowledge of how to finance a business. Students were rather sceptical, they were more willing to answer: I hold a good knowledge rather than to be overoptimitic and say: very good. We would claim that this is a positive sign, showing a modest attitudes of students but also not possessing a very good knowledge may be a reson why students are not so entrepreneurial. The highest assessment was appointed to knowledge how to legally get the money (43\%). The lowest score was appointed to techniques of market research. The results are also presented on whisper plot (Fig. 5) which indicates the assessment in terms of grades appointed. Because this is self-assessmenet of students so the limitation of these answers may be related to underestimation own skills.

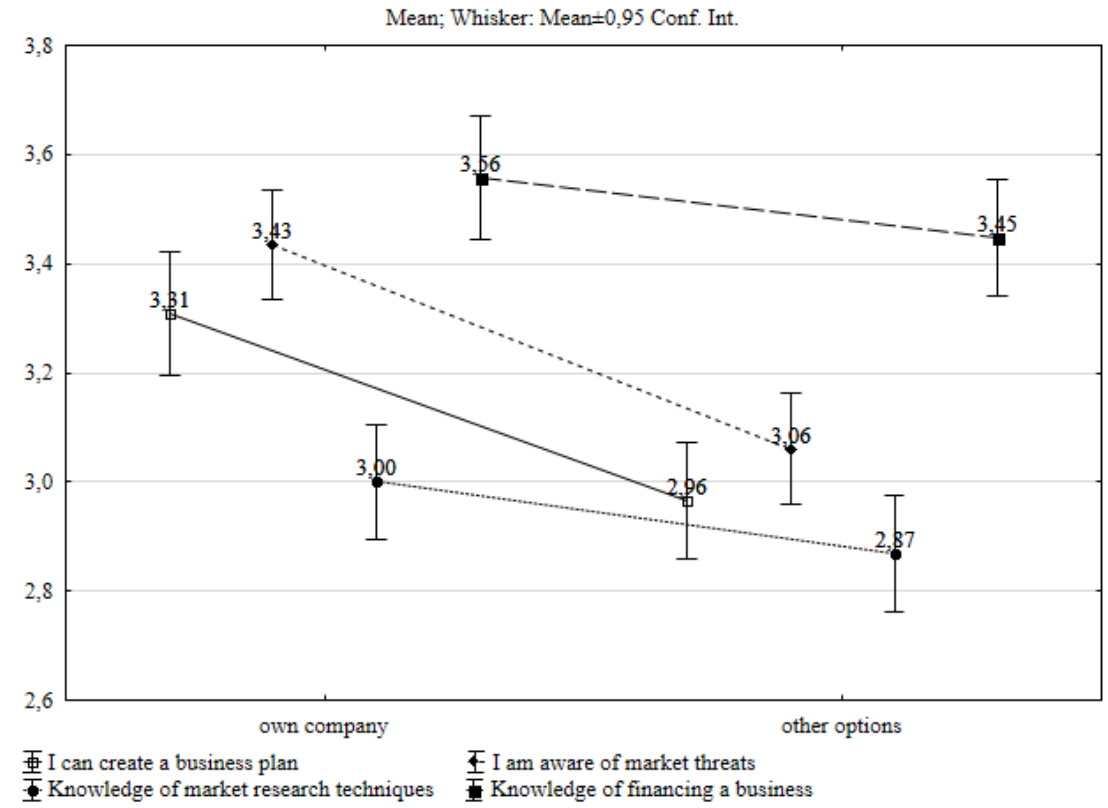

Figure 5. Interaction plot

Source: Own development, $\mathrm{n}=566$.

Generally students who are more entrepreneurial (they want to set up their business) better assess their entrepreneurial skills. The ranking is lead by skills related to financing a business 3.56 for students willing to set up their business and 3.45 for those who want to work for someone. Using U Mann-Whitney test we meant to confirm or reject $\mathrm{H}_{3}$ hypothesis to find out if there are differences in answers in two group of students: the one who are willing to set up their own business and other options (working for someone). The test proved two significant differences in skills: I can create a business plan $p<\alpha(p=0,0000)$ and I am aware of market threats $\mathrm{p}<\alpha(\mathrm{p}=0,0000)$. The results are presented in Table 2 . 
Table 2. Assessment of skills in two groups: Entrepreneurial students and other option

\begin{tabular}{|l|c|}
\hline Assessment of entrepreneurial skills & p-value \\
\hline I can create a business plan & $0,0000^{* * *}$ \\
\hline I am aware of market threats & $0,0000 * * *$ \\
\hline I know market research techniques & 0,0862 \\
\hline I know how to finance a business & 0,1692 \\
\hline
\end{tabular}

Source: Own development, $\mathrm{n}=566$.

$* \mathrm{p}<0.05-$ statstically significant

$* * \mathrm{p}<0.01-$ statistically medium significant

$* * * \mathrm{p}<0.001-$ statistically highly significant

The $\mathrm{H}_{3}$ is partially confrmed related to skills: knowledge of market research techniques and knowledge on finnacing a business.

\section{CONCLUSIONS}

In the last decade, there has been growing interest in undertaking and intensifying actions to promote and support the idea of entrepreneurship as an attractive alternative to wage employment among students not only in Poland but also around the globe. There are several reasons for this tendency. First, well-educated entrepreneurs are expected to create ventures that grow faster than the enterprises of their counterparts. Secondly, entrepreneurs are recognized as important drivers of economic and social progress, and entrepreneurial initiatives for young people are regarded as an important factor in the future growth of a nation. Consequently, universities are expected to play a major role in propagating an entrepreneurial attitude among students and graduates and nurturing future entrepreneurs. This explains why a growing number of universities start to offer specialized entrepreneurship courses and programs in their business curriculum. There is a general belief that good students will be more entrepreneurial and we abolished this belief in our research.

The aim of this study was to assess how grades influence students' entrepreneurial attitudes. We proved that apart from teaching students how to set up their business, an important aspect is attributed to willingness of taking a risk. Not the best students are willing to set up a business but an average students. Students are rather pessimistic in estimating their entrepreneurial skills which might be due to several reasons: the majority of students were second year students and they may belive that underestimating their skills offers them still a long way to study. Our results partially contradict Roxas et al. ${ }^{45}$ who claim that knowledge gained from formal entrepreneurship education programmes will boost individual entrepreneurial intentions. It will boost student's enterpreneurial attitudes, but once we have taken into account individuals predispositions for setting up a business. An important aspect which differentiates an employee and entreprenur is being responsible for the whole company and taking the risk that the business may not succed ulimately.

${ }^{45}$ B.G. Roxas, R. Cayoca-Panizales, Entrepreneurial knowledge and its effects on entrepreneurial intentions: development of a conceptual framework, "Asia-Pacific Social Science Review" 2008, Vol. 8, No. 20, p. 61-77. 
We value formal education but we strongly support to analyze individual predispositions in assessing someone's entrepreneurial attitudes. By providing the necessary knowledge in the teaching system and the distinction in the attitude of teaching entrepreneurship education in relation to young people entering the labor market. Willingness to set up a business may be related to fact, that the Polish culture does not accept failure. What we mean is that an enterpreneur is regarded as „stupid“ without necessary knowledge and skills when their fail, nobody takes into account that that failure could have been related to external environmet, factors that could have been beyond an entrepreneur control.

The research results are part of a bigger research project that aims to investigate entrepreneurial attitudes of students in Thailand, UK, USA and Canada.

This study provides compelling evidence that students want to start their entrepreneurial activity after gaining a few years of work experience, grades strongly differentiate the entrepreneurial attitudes. Not the best students are the most entrepreneurial. This might be related to propensity for risk taking. Therefore next research should incorporate risk attitude along with the national culture aspect. It would be inappropriate to generalize these results to actual entrepreneurial behaviours until such a relationship is confirmed by other empirical research. Also the findings are not universally applicable to any country as the education system needs to be analysed beforehand.

Our results are based solely on the self-evaluation of students, regarding their capability and awareness about starting a new business venture. This could have a strong impact on their perceptions and intentions. Further research could investigate whether the students have over-estimated or under-estimated their proficiency, and the extent to which the selfevaluations reflect their actual skills and the consequent impact on entrepreneurial ability.

\section{REFERENCES}

1. Abaho E., Olomi D.R., Urassa G.C., Students' entrepreneurial self-efficacy: does the teaching method matter?, "Education + Training" 2015, Vol. 57, No. 8/9.

2. Acs Z.J., Megyesi M.I., Creativity and industrial cities: a case study of Baltimore, "Entrepreneurship and Regional Development: An International Journal" 2009, Vol. 21, No. 4.

3. Adcroft A., Dhaliwal S., Willis R., Insatiable demand or academic supply: the intellectual context of entrepreneurship education, "European Business Review" 2005, Vol. 17, No. 6.

4. Anderson A., Jack S., Role typologies for enterprising education: the professional artisan?, "Journal of Small Business and Enterprise Development" 2008, Vol. 15, No. 2, http://dx.doi.org/10.1108/14626000810871664.

5. Azhar A., Javaid A., Rehman M., Hyder A., Entrepreneurial intentions among business students in Pakistan, "Journal of Business Systems, Governance and Ethics" 2010, Vol. 5, No. 2.

6. Baldassarri S., Saavala T., Entrepreneurship - educating the next generation of entrepreneurs, "Enterprise Europe" 2006, Vol. 22, July.

7. Blazyca G., Heffner K., Helinska-Hughes E., Poland - can regional policy meet the challenge of regional problems?, "European Urban and Regional Studies" 2002, Vol. 9, No. 3.

8. Chung, J.T., Risk reduction in public accounting firms: are women more effective?, "International Review of Women and Leadership" 1998, Vol. 4, No. 1. 
9. Clawson T., UK Universities gear up for enterprise education, 2014, www.forbes. com/sites/trevorclawson/2014/12/16/uk-universities-gear-up-for-enterprise-education/ (access: 15 December 2014).

10. Davidsson P., Research Entrepreneurship. Springer, New York.

11. Davidsson P., The Domain of Entrepreneurship Research: Some Suggestions, In: „Advances in Entrepreneurship, Firm Emergence and Growth", Ed. J.A. Katz, 2005.

12. Dyduch W., Corporate entrepreneurship measurement for improving organizational performance, ,Journal of Economics and Management” 2008, Vol. 4.

13. Farooq M.S., Salam M., UrRehman S., Fayolle A., Jaafar N., Ayupp K., Impact of support from social network on entrepreneurial intention of fresh business graduates: a structural equation modeling approach, "Education + Training" 2018, Vol. 60, No. 4.

14. Foley P., Hutchinson J., Kondej A., Mueller J., Economic development in Poland: a local perspective. "European Business Review" 1996, Vol. 96, No. 2, http://dx.doi.org/10.1108/ 09555349610111839.

15. GEM (2009), GEM-MENA Regional Report 2009 (Middle East \& North Africa), Global Entrepreneurship Monitor, Kauffman Foundation, Kansas City, MO.

16. Global Entrepreneurship Monitor (GEM) (2014), 2014 Global Report, Global Entrepreneurship Monitor, Kauffman Foundation, Kansas City, MO.

17. Gorman G., Hanlon D., King W., Some research perspectives on entrepreneurship education, enterprise education and education for small business management: a ten-year literature review, "International Small Business Journal" 1997, Vol. 15, No. 3, http://dx.doi. org/10.1177/0266242697153004.

18. Gries T., Naudé W.A., Entrepreneurship and structural economic transformation, „Small Business Economics Journal” 2010, 34 (1).

19. Gummesson E., Relationship marketing in the new economy, „Journal of Relationship Marketing" 2002, Vol. 1, No. 1.

20. Jack S.L., Anderson A.R., Entrepreneurship education within the enterprise culture, "International Journal of Entrepreneurial Behaviour \& Research" 1999, Vol. 5, No. 3, http://dx.doi.org/10.1108/13552559910284074.

21. Jiménez-Moreno J.J., Wach K., The entrepreneurial profile of students. Participating in the Academic Entrepreneurship Course: Pilot Study Results. "Horyzonty Wychowania" 2014, Vol. 13, No. 26.

22. Johansen V., Schanke, T., Clausen, T.H., Entrepreneurship education and pupils: attitudes towards entrepreneurs, 2012, available at: www.intechopen.com (access: 11 August 2013).

23. Katz J., Chronology and intellectual trajectory of American entrepreneurship education 1876-1999, "Journal of Business Venturing” 2003, Vol. 18, No. 2.

24. Kevane M., Wydick B., Microenterprise lending to female entrepreneurs: Sacrificing economic growth for poverty alleviation?, „World Development” 2001, 29 (7).

25. Kierulff H.E., Entrepreneurship in Poland: findings from the field, "Human Factors and Ergonomics in Manufacturing" 2005, Vol. 15, No. 1.

26. Kostera M., Differing managerial responses to change in Poland, "Organization Studies" 1995, Vol. 16, No. 4.

27. Kuratko D.F., The emergence of entrepreneurship education: development, trends and challenges, "Entrepreneurship Theory and Practice" 2005, Vol. 29, No. 5, http://dx.doi. org/10.1111/j.1540-6520.2005.00099. 
28. Liñán, F. (2008), "Skill and value perceptions: how do they affect entrepreneurial intentions?", International Entrepreneurship and Management Journal” 2008, Vol. 4, No. 3.

29. Matlay H., Carey C., Entrepreneurship education in the UK: a longitudinal perspective. "Journal of Small Business Enterprise and Development" 2007, Vol. 14, No. 2, http://dx. doi.org/10.1108/14626000710746682.

30. Matlay H., Researching entrepreneurship and education: what is entrepreneurship and does it matter?, "Education and Training" 2005, Vol. 47, No. 8/9.

31. McGowan P., Sijde P., Kirby D., The role of universities in the entrepreneurship industry: promoting the entrepreneurship agenda in HEIs, "Industry and Higher Education" 2008, Vol. 22, No. 1, http://dx.doi.org/10.5367/ 000000008783876986.

32. Milius P., Sarkiene J., Entrepreneurship training for innovative start-ups: the KTC case, in van der Sijde, P., Annemarie Ridder, A., Blaauw, G. and Diensberg, C. (Eds), Teaching Entrepreneurship, ISBN 978-3-7908-2038-6, Physica-Verlag HD, Heidelberg 2008, http://dx.doi.org/10.1007/978-3-7908-2038-6_4.

33. Minniti M., Naudeé W., What Do We Know About The Patterns and Determinants of Female Entrepreneurship Across Countries? „The European Journal of development Research“" 2010, Vol. 22, Issue 3.

34. Mueller S.L., Thomas A.S., Culture and entrepreneurial potential: a nine country study of locus of control and innovativeness, "Journal of Business Venturing" 2000, Vol. 16, http://dx.doi.org/10.1016/S0883-9026(99)00039-7.

35. Nikodemska-Wołowik A.M., Family enterprises - a chance to create a strong Polish identity. "The Marketing Review" 2006, Vol. 6, No. 4.

36. Pittaway L., Cope J., Entrepreneurship education: a systematic review of the evidence. Working Paper Series No. 2, National Council for Graduate Entrepreneurship, Birmingham, 2006, http://dx.doi.org/10.1177/0266242607080656.

37. Por J.T., White J., An entrepreneur's guide to Eastern Europe, "European Business Review" 1991, Vol. 94, No. 3.

38. Reichal J., Rudnicka A., Collaboration of NGOs and business in Poland, "Social Enterprise Journal" 2009, Vol. 5, No. 2, http://dx.doi.org/ 10.1108/17508610910981716.

39. Raport, Przedsiębiorczość kobiet w Polsce (Women entrepreneurship in Poland, 2011, PARP, 2011.

40. Reynolds P.D., Hay M., Camp S.M., Global Entrepreneurship Monitor: 1999 Executive Report, Kauffman Centre for Entrepreneurial Leadership at the Ewing Marion Kauffman Foundation, Kansas City, MO, 1999.

41. Roxas B.G., Cayoca-Panizales R., de Jesus R., Entrepreneurial knowledge and its effects on entrepreneurial intentions: development of a conceptual framework, "Asia-Pacific Social Science Review” 2008, Vol. 8 No. 20, http://dx.doi.org/10.3860/apssr.v8i2.784.

42. Safin K., Przedsiębiorcze zachowania studentów - stan i konsekwencje dla dydaktyki (Entrepreneurship of students - the current state and the consequences for didactics), "Horyzonty Wychowania" 2014, Vol. 13, No. 26.

43. Salam, M., Iskandar, D.N.F.A. and Ibrahim, D.H.A., Service learning support for academic learning and skills development, Journal of Telecommunication, Electronic and Computer Engineering" 2017, Vol. 9, No. 2-10.

44. Santoro M., Chakrabarti A.K., Firm size and technology centrality in industry-university interactions, ,Research Policy” 2003, Vol. 31. 
45. Schindehutte M., Morris M., Brennan C., Entrepreneurs and motherhood: Impacts on their children in South Africa and the United States, "Journal of Small Business Management" 2003, 41 (1).

46. Scherer R.F., Brodzinski J.D., Wiebe F., Examining the relationship between personality and entrepreneurial career preference, "Entrepreneurship \& Regional Development" 1991, Vol. 3, No. 2.

47. Siguaw J.A., Bakes T.L., Simpson P.M., Preliminary evidence on the composition of relational exchange and its outcomes: the distributor perspective, ,Journal of Business Research" 2003, Vol. 56.

48. Smallbone D., Welter F., The role of government in SME development in transition economies, "International Small Business Journal" 2001, Vol. 19, No. 4, http://dx.doi.org/ $10.1177 / 0266242601194004$.

49. Slovic P., The Perception of Risk, Earthscan Publications Ltd, London 2000.

50. Socha M., Weisberg J., Labour market transition in Poland - changes in the public and private sectors, "International Journal of Manpower" 2002, Vol. 23, No. 6.

51. Sołek-Borowska, Chudy-Laskowska K., Exploring entrepreneurial attitudes of students in Poland C.: An interregional comparison, University of Economics in Katowice, Katowice 2017.

52. Soomro B.A., Shah N., Developing attitudes and intentions among potential entrepreneurs, "Journal of Enterprise Information Management" 2015, Vol. 28, Issue: 2, http://dx.doi.org/ 10.1108/JEIM-07-2014-0070.

53. Szerb L., The changing role of entrepreneur and entrepreneurship in network organisations, Knowledge Transfer, Small and Medium-Sized Enterprises, and Regional Development in Hungary, JATE Press, Hungary, 2003, K. Lengyel (Trans.).

54. Wach K., Edukacja przedsiębiorcza: analiza bibliometryczna polskiego piśmiennictwa (Entrepreneurship: bibliometric analysis of Polish literature), "Horyzonty Wychowania", Vol. 15, No. 34, 2016, http://doi: 10.17399/ HW.2016.153401.

55. Wach K., Środowisko biznesu rodzinnego jako stymulanta intencji przedsiębiorczych mtodzieży akademickiej (The family business environment as a stimulant for the entrepreneurial intentions of the academic youth), "Przedsiębiorczość i Zarządzanie" 2015, XVI (7(III)).

56. Waters C., Changing the role of the retail sector in Poland during a period of economic transition, "International Journal of Retail \& Distribution Management" 1999, Vol. 27, No. 8 .

57. Węcławska D., Zadura-Lichota P., Wptyw edukacji na postawy przedsiębiorcze i przygotowanie młodych Polaków do prowadzenia działalności gospodarczej (The impact of education on entrepreneurial attitudes and preparation of young Poles to do business), In: A. Wilmańska (ed.), Raport o stanie sektora matych i średnich przedsiębiorstw $w$ Polsce $w$ latach 2008-2009 (Report on the state of small and medium enterprises in Poland in 2008-2009), 2010.

58. Winkler C., Toward a dynamic understanding of entrepreneurship education research across the campus-social cognition and action research, Entrepreneurship Research Journal" 2014, Vol. 4, No. 1.

59. Williams, D.R., Effects of childcare activities on the duration of self-employment in Europe, „Entrepreneurship Theory and Practice” 2004, 28 (5).

60. Zioło Z., Miejsce przedsiębiorczości w edukacji (Place of the entrepreneurship in education), "Przedsiębiorczość - Edukacja" 2012, Vol. 8. 


\section{OCENA UMIEJĘTNOŚCI PRZEDSIĘBORCZYCH STUDENTÓW ORAZ ICH PODEJŚCIA DO PRZEDSIĘBIORCZOŚCI}

Przedsiębiorczość jest często definiowana jako oportunistyczne poszukiwanie bogactwa ekonomicznego w obliczu ograniczonych zasobów. Rządy na całym świecie podejmują wiele programów mających na celu wzmocnienie postaw przedsiębiorczych wśród studentów - potencjalnych przedsiębiorców. Uzyskane korzyści są znaczące, takie jak: tworzenie miejsc pracy, innowacje i ostatecznie wkład w narodowe bogactwo gospodarcze. Rola i wpływ edukacji, w tym szkoleń, jest głównym tematem dyskusji w ostatniej dekadzie. Pojęcie „kształcenie w zakresie przedsiębiorczości" odnosi się do holistycznego podejścia zalecanego w miejsce tradycyjnej edukacji na temat zasad prowadzenia firmy. Celem niniejszego badania jest ocena postaw przedsiębiorczych studentów w stosunku do ocen, jakie uzyskują na studiach, oraz ocena przedsiębiorczych umiejętności studentów. Ankiety papierowe posłużyły do zbadania studentów studiujących w Szkole Głównej Handlowej w Warszawie i Politechnice Rzeszowskiej w Rzeszowie. Respondentami byli studenci studiów licencjackich uczestniczący w module Zarządzania Szkoły Głównej Handlowej i Metod Statystyki na Politechnice Rzeszowskiej. Średnia ocen uzyskanych podczas studiów mocno różnicuje plany studentów po zakończeniu studiów. Studenci ze średnią ocen 3,5-3,99, wykazują najbardziej przedsiębiorcze postawy ponieważ $19 \%$ z nich chciałoby rozpocząć swoją działalność. Najlepsi studenci (z najwyższymi ocenami) są najmniej przedsiębiorczy, tylko $6 \%$ z nich chciałoby założyć firmę. Jest to sygnał dla osób związanych z nauczaniem przedsiębiorczości, że postawy przedsiębiorcze nie są tylko wyłącznie związane z edukacją, ale należy wziąć pod uwagę inne czynniki, takie jak indywidualne predyspozycje, np. chęć podjęcia ryzyka.

Słowa kluczowe: przedsiębiorczość, edukacja przedsiębiorcza, umiejętności przedsiębiorcze.

DOI: 10.7862/rz.2018.mmr.54

Tekst złożono do redakcji: październik $2018 \mathrm{r}$.

Tekst przyjęto do druku: grudzień 2018 r. 
